NBER WORKING PAPER SERIES

CHANGES IN THE PROCESS OF AGING

DURING THE TWENTIETH CENTURY:

FINDINGS AND PROCEDURES OF THE

EARLY INDICATORS PROJECT

\author{
Robert W. Fogel \\ Working Paper 9941 \\ http://www.nber.org/papers/w9941 \\ NATIONAL BUREAU OF ECONOMIC RESEARCH \\ 1050 Massachusetts Avenue \\ Cambridge, MA 02138
}

August 2003

This paper was prepared for the RAND Summer Institute on Demography, Economics, and Epidemiology of Aging Tenth Anniversary Gala of the NIA. P30 Program, July 11-12, 2003, Santa Monica, CA. I have benefited from the comments and criticisms on an earlier draft by Amy Aiseirithe, Dawn Alley, Javier Birchenall, Peter Blanck, Dora Costa, Lance Davis, Bernard Harris, Elaine Heisler, Max Henderson, Kwangsun Lee, Robert Margo, Robert Mittendorf, Douglass North, Louis Nguyen, Georgeanne Patmios, Robert Pollak, Melissa Ptacek, Nevin Scrimshaw, Kenneth Sokoloff, Chen Song, Dejun Su, Richard Suzman, James Tanner, Werner Troesken, Sven Wilson, and E. A. Wrigley. The Early Indicators project is funded by NIA grant P01 AG10120. The views expressed herein are those of the authors and not necessarily those of the National Bureau of Economic Research.

(C)2003 by Robert W. Fogel. All rights reserved. Short sections of text, not to exceed two paragraphs, may be quoted without explicit permission provided that full credit, including $($ ) notice, is given to the source. 
Changes in the Process of Aging During the Twentieth Century:

Findings and Procedures of the Early Indicators Project

Robert W. Fogel

NBER Working Paper No. 9941

August 2003

JEL No. I10, I12, J11, J14

\begin{abstract}
$\underline{\text { ABSTRACT }}$
The program project Early Indicators of Later Work Levels, Disease and Death investigates how socioeconomic and environmental factors in early life can shape health and work levels in later life. Project researchers have approached this problem by creating a life-cycle sample that permits a longitudinal study of the aging of Union Army veterans, the first cohort to reach age 65 during the twentieth century. Comparing Union Army data with data from NHANES and NHIS has shown that age-specific prevalence rates of specific chronic diseases and disabilities were much higher in the century before World War II among both young and old than today. Moreover, the number of comorbidities at each age has fallen sharply. Also, the average age at onset of chronic diseases was more than a decade later at the end of the twentieth century than at the beginning. The implications of these findings for several issues in health economics are discussed.
\end{abstract}

Robert W. Fogel

Graduate School of Business

University of Chicago

1101 East $58^{\text {th }}$ Street

Chicago, IL 60637

and NBER

rwf@cpe.uchicago.edu 


\section{Changes in the Process of Aging during the Twentieth Century: Findings and Procedures of the Early Indicators Project}

The results to date of the program project called Early Indicators of Later Work Levels, Disease and Death have exceeded expectations in 1986, when we began our work on it, because so many of the findings were unanticipated. The original aim was to create a life-cycle sample that would permit a longitudinal study of the aging of Union Army veterans. Born mainly between 1830 and 1847, these veterans were the first cohort to turn age 65 during the twentieth century. It was possible to create the life-cycle sample by linking together information from about a dozen sources, including the manuscript schedules of censuses between 1850 and 1910; regimental, military, and medical records; public health records; Union Army pension records; surgeons' certificates giving the results of successive examinations of the veterans from first pension application until death; death certificates; daily military histories of each regiment in which the veterans served; and rejection records of volunteers.

The original plan was to draw a random sample of 39,300 recruits from the regular regiments of the army. Since that sample produced too few black veterans, we subsequently enlarged the sample by drawing about 6,000 veterans from the black regiments. All told, the completed sample consists of about 45,300 observations. It takes about 15,000 variables to describe the complete life-cycle history of each veteran.

The program project was funded by NIA in 1991 and has been extended by competitive applications in 1994 and 2001, each time for 5 years. About 80 percent of the effort during the first two grant periods was devoted to creating the life-cycle sample, and about 20 percent for analysis. Under the current award about 20 percent is for the extension of the sample, 10 percent for outreach (to make this complex data set more accessible to investigators outside of the program project), and about 70 percent for data analysis. 
When the Early Indicators project began, it was led by a team of 7 senior investigators and 4 consultants. Of these, 4 were primarily economists, one was a demographer, one was a specialist in biological anthropology, and 5 were physicians. The large team of physicians reflected the central role assigned to biomedical issues and their interaction with socioeconomic factors. The biomedical group has been headed by Nevin Scrimshaw who was trained in biology, medicine, public health, and epidemiology. He has been the principal investigator and consultant in several major field studies concerned with the effectiveness of public health and nutritional interventions on morbidity and mortality. He not only greatly influenced our approach to biomedical issues, but profoundly influenced the entire strategy of the project. Two other physicians deeply involved in the shaping of the strategy were Irwin H. Rosenberg, a gastroenterologist and head of the U.S.D.A. Human Nutrition Center on Aging at Tufts University, and J. M. Tanner of London University, a specialist in pediatric endocrinology, human growth, and the use of anthropometric measures as indexes of nutritional status and general health.

The output of the project has been substantial. So far the project has produced 74 published papers, 5 books, and 6 Ph.D. dissertations. Another 5 papers have been accepted for publication. Dora Costa's book, The evolution of retirement: An American economic history, 1880-1890, won the Paul A. Samuelson prize for 1998 awarded by TIAA/CREF. Three more dissertations are in progress. There are about 40 working papers completed or in progress. So far 11 manuals for data users have been published and CD-ROMs containing data have been distributed.

Many of the findings of the Early Indicators project were unanticipated, and they significantly altered our research strategy as we proceeded. Of these unanticipated findings, 
perhaps the most surprising was the discovery that chronic diseases began earlier in the life cycle and were more severe at the beginning of the twentieth century than at the end of it. This finding was surprising because leading epidemiologists and demographers writing in the 1980s and early 1990s found what appeared to be credible evidence that the extension of life expectancy had brought with it worsening health (Verbrugge 1984 and 1989; Alter and Riley 1989; Riley 1989. Cf. Riley 1990a and 1990b; Riley 1997; Riley and Alter 1996; Wolfe and Haveman 1990; Verbrugge and Jette 1994; Waidmann, Bound and Schoenbaum 1995). By the early 1990s that proposition had evolved into the "Theory of the Health or Epidemiological Transition," a gloss on an idea originally proposed by A. R. Omran, not to describe the change in the pattern of morbidity, but to describe the change in the pattern of mortality: from mainly deaths due to acute diseases to mainly deaths due to chronic diseases (Omran 1971; Murray and Chen 1992, 1993a and 1993b).

\section{Questions about the Feasibility of the Research Design}

At the time that we began the preliminary research into constructing a longitudinal sample of aging based on Union Army veterans, there were no laptops that could be carried into archives and no commercial software for the management of the databases as large as the one we contemplated (15,000 variables on close to 40,000 observations), even on mainframes. There was no previous experience with creating longitudinal aging samples based on micro-data constructed by linking together information on particular individuals from a dozen or more different data sets covering nearly the whole life cycle of these individuals. Moreover, the desired data for our project were deposited in archives, especially in Washington, D.C. and in Utah, that were not accustomed to the traffic we created. 
Critics of the project found the undertaking highly dubious. They felt we were pushing computers and sampling techniques beyond their capacity, and in a sense we were. Fortunately, the advances in both computer hardware and software were so rapid that we were not ahead of this technology but at its leading edge, continually modifying analytical techniques and research design to take maximum advantage of the rapidly evolving technology.

\section{Organizing the Data Retrieval and Processing}

Still another challenge was organizational. We had to create a network of data retrievers, inputters, checkers, and programmers capable of putting the data we needed into machinereadable form with accuracy, efficiency, and at a low enough cost to make the enterprise viable. That organizational feat was accomplished by Larry T. Wimmer of Brigham Young University. He exploited the talent of students at his university who, because of their interest in constructing their own family genealogies, were already familiar with archival research. He created a training program to introduce successive teams of students to the specific skills needed for work in the records of the U.S. National Archives and the microfilm holdings of the Family History Library in Salt Lake City. For much of the first 10 years of the project Wimmer was supervising about 75 data retrievers, inputters, coordinators, programmers, and analysts. Because of the tightness and efficiency of the operation, Wimmer was able to keep the cost of transforming the data into machine readable form remarkably low, thus contradicting the forecasts of critics who thought that the cost of the Early Indicators project would exceed acceptable bounds.

\section{Evaluating Sample Selection and Other Biases}

Perhaps the most formidable obstacle to the design of the Early Indicators project pertained to the reliability and range of applicability of the synthetic longitudinal sample we aimed to base on the military and pension records of the Union Army. Prior to 1991 it was 
widely doubted that a useful prospective sample on aging for either an extinct or a living cohort could be created synthetically, given the numerous risks of failure. Much of the skepticism was focused on the pension records that were said to be corrupted by agents who sought pensions for bogus veterans and by pension physicians who were bribed to report non-existent disabilities. Census records, it was said, were more reliable and preferable.

Where the quality of census and pension records can be compared, as in the case of variables that appear in both, such as name, place of birth, and age, the pension records are far superior. Census records are subject to frequent name misspellings, often because the census taker put down a variant spelling. Age and place of birth are often in error in the census because the respondent did not know the place of birth of all residents in the household, or because of spelling errors for small European principalities. Census records also suffer from age heaping and poor memory. In the pension records, by contrast, numerous documents are provided to support claims on name, age, and place of birth, including birth records, baptismal records, enlistment and discharge papers, marriage certificates, affidavits by neighbors and company officers, and death certificates. ${ }^{1}$

The contention that there would be a void of information in the Union Army and pension records between ages 25 and 65 (between discharge from the Union Army and enrollment in the pension) also turned out to be wrong. About 80 percent of all of the medical examinations of the veterans pertains to those ages. There are frequent listings by both age and date of occupation, residence, and health conditions during these ages. ${ }^{2}$

Sample selection biases due to linkage failure turned out to be far less severe than critics conjectured. Logit and OLS regressions were run to identify factors that affected the odds of linking recruits to the various censuses, military and pension records. The eleven behavioral 
variables used as predictors are attributes obtained from the recruits sample. The main finding of these regressions is that being foreign born was the principal nonrandom factor accounting for the failure of linkage to the 1850 and 1860 censuses. In linking to the 1900 and 1910 censuses, being a foreigner is much less important in explaining linkage failure than in the prewar case. The discrepancy is due primarily to the fact that about two-thirds of the foreign-born recruits arrived in the U.S. after June 1, 1850 and about 7 percent arrived after June 1, 1860 and hence were not covered by the census. ${ }^{3}$ In the case of the pension records, "died during the war" and being a deserter are the principal reasons for nonrandom linkage failure. ${ }^{4}$

The predictability of the factors that explain linkage failure indicates that biases introduced by censoring can be corrected by reweighting subsamples having the relevant characteristics (this applies to subgroups overrepresented as well as those underrepresented). However, tests revealed that reweighting had very little effect on estimates of key parameters.

Several other tests of the representativeness of the linked sample were undertaken. One of these concerned the wealth distribution of all adult males (age 20 and over) in the households to which the recruits were linked in the 1860 census. The distribution was lognormal and not significantly different from Lee Soltow's (1975) random sample of the wealth of northern males age 20 and over in 1860.

The most difficult problems of inference related to screening problems stem from the varying date of entry into the pension records. The governing principle in dealing with such data is that individuals are not at risk for most purposes until they applied for the pension. Life tables constructed on this principle for the period circa 1900 are similar to the mortality schedules constructed from the death registration data but are somewhat lower, as is to be expected, since 
the areas covered by death registration in 1900 were still concentrated in the high-mortality locations (Preston, Keyfitz and Schoen 1972; Preston and Haines 1991).

\section{The Prehistory of the Early Indicators Project}

Given the widespread doubts about the feasibility of the Early Indicators project, it is worth considering how it ever got off the ground. The answer to that question lies in the prehistory of this project, which covers the period between 1955 and 1985. Those three decades produced a group of economists, well trained in the new mathematical models and statistical techniques of their discipline, who were focused on the explanation for modern, long-term economic growth. This group of economists, who came to be called "cliometricians," sought to exploit the potentialities of the newly developed high speed computers, typified by the IBM 650 mainframe computer, which began to be installed at leading research universities across the country at deep discounts if the universities would agree to offer courses to students and faculty in how to use them (Ceruzzi 2003).

I was exposed to a one-week course in how to program the 650 at Columbia University in the spring of 1957, as were many other cliometricians about that time. Such exposure was not enough to master the art, but it awakened in us the realization that a new era was at hand, in which mountains of microdata sets that were lying unexploited in various archives could now be put to use in the quest for empirically well-founded answers to the sources of American economic growth during the previous 150 years, and in the future.

In the mid-1960s, William N. Parker of Yale University and Robert A. Gallman of the University of North Carolina, with the aid of a group of their graduate students, sought to retrieve information from one of these mountains of neglected data: the "manuscript schedules" of the U.S. decennial census of 1860 . These were the original sheets of paper that the census 
takers carried around to each household, farm, and business together with instructions from Washington on how to fill them out. Since there were over $6,000,000$ of these schedules collected for the 1860 census, Parker and Gallman decided to draw a random sample of about 5,000 of the farm households with which they were concerned, thus initiating the problem of how to design random samples of archival data.

They initiated still another problem. The focus of their research was the study of the institution of slavery and the comparative analysis of the operation of free farms and large slave plantations in the cotton-producing counties of the South. That objective required them to link together information from three of the six schedules that constituted the 1860 census. Other investigators sought to link plantations to the same information in both the 1850 and 1860 censuses (Menn 1964a and b; Wilcox 1992; cf. Foust 1968). Thus began the process of creating synthetic, longitudinal data sets by linking together information from several sources over space and time. ${ }^{5}$

Another aspect of the prehistory was the discovery of a large number of genealogies that could be used to recreate the vital statistics of the United States, going back to early colonial times. The U.S. death registration system did not begin until 1890 and at first embraced only 10 states. It did not become national until the 1930s. National trends in mortality rates prior to 1890 were unknown, except for the inaccurate, but usable, data collected by the decennial censuses between 1850 and 1900 . Trends prior to 1850 were a void, with leading historical demographers at odds with each other's conjectures based on isolated fragments of information.

There are both published and unpublished genealogies. The published genealogies consist of volumes that attempt to describe all the descendants of a particular patriarch down to current times. A ten-generation book, if complete, could have well over 50,000 individuals in it. Many of 
these volumes are on deposit in the Library of Congress, the Newberry Library in Chicago, and the Family History Library in Salt Lake City. It has been estimated that at least 60,000 of these volumes are in existence for the United States covering over 100 million individuals (Fogel et al. 1978; Fogel 1993).

There are also large numbers of unpublished genealogies, many of which exist only in the households of individual genealogists and are difficult to access. However, a large collection of these unpublished genealogies are on deposit at the Family History Library in Utah, which is a part of the Church of Jesus Christ of Latter Day Saints (Mormons). ${ }^{6}$

Work with both published and unpublished genealogies demonstrated that they were representative of the living population when proper attention was given to a variety of selection biases, many of which were novel and peculiar to genealogies. ${ }^{7}$ Moreover, the information in the genealogies not only made it possible to calculate the mean odds of dying at each stage in the life cycle for particular cohorts, but to run regressions that made the odds of dying $\left({ }_{n} q_{x}\right)$ at any age interval, period or cohort a function of such variables as birth order, parents' and grandparents' age at death, ages of death of collateral kin, mother's age at birth, extent of geographic mobility, the number of generations that ancestors of the family were located within the United States, and SES variables that could be treated both immediately and intergenerationally. ${ }^{8}$

Yet another aspect of the prehistory is our introduction to the uses of anthropometric data. In 1974 Stanley Engerman and I published Time on the Cross, in which we used data from probate records to calculate the ages of slave women at their first birth. The exercise yielded an average figure of 22 years. Since the standard sources suggested that slave women were generally fecund in their mid-teens, and since slaves were not using contraception, we conjectured that most slave women must have abstained from sexual intercourse for 6 or 7 years, 
probably until, or in contemplation of, marriage. That analysis was challenged by critics who argued that the use of probate records biased the calculated age of first birth upward by at least 4 years. They also argued that slaves could not have become menarcheal until at least age 18 . Since (according to J. M. Tanner) Norwegian girls did not become menarcheal until age 17, they argued that U.S. slaves could not have done so until at least a year later because their diets were so much worse that the diets of Norwegian girls. ${ }^{9}$

Engerman and I were aware of both upward and downward biases when using probate records (which were cross-sectional) to calculate the mean age at first birth. In grappling with the issues raised by the critics, we worked out a theoretical argument to show that upward and downward biases would tend to cancel out. We sent Ansley Coale a letter with our results, asking for his assessment of it. Coale passed our letter on to James Trussell, then a young assistant professor in the Office of Population Research at Princeton, who became interested in our problem. Since he would be spending 1975-76 at the London School of Tropical Medicine working with William Brass, a leading mathematical demographer, while I was visiting at Cambridge University, Trussell suggested that we get together after we had both settled in.

Early that fall, Trussell came up to Cambridge and gave me what I can only describe as a brilliant lecture on the singulate mean, a statistic invented by J. Hajnal to eliminate types of biases that arise when using cross-sectional data to estimate the mean age of marriage in a cohort of women, which Trussell extended to the fertility schedule. Working with Richard Steckel (Trussell and Steckel 1978), and using data drawn from both probate and plantation records, Trussell estimated that the mean age of marriage was about 21 years.

When Trussell reported the good news, he added that there was a problem because the age of menarche was still open, but that it could be estimated from information on weight by age 
or height by age. Engerman and I had collected thousands of observations on height by age from the coastwise manifests of U.S. Customs as a byproduct of our work on the internal slave trade. We had been wondering for years what we might do with such data. At the suggestion of Richard Wall of the Cambridge Group, Engerman had written a note for Local Population Studies using the cross-sectional data from a subsample of the coastwise manifests to represent the growth profiles in height of male and female slaves. When I showed the profiles to Trussell, he recommended that we show them to James Tanner, who had shown that the mean age of menarche of a population could be estimated by constructing the age-for-height curve from cross-sectional data. He had also shown that the age of menarche followed the peak in the teenage growth spurt by about one year. When we showed Tanner our sample, he suggested that the peak of the teenage growth spurt was probably about thirteen or fourteen, but warned that a large sample would have to be collected before the issue could be settled.

Thus began our research on the use of anthropometric data to estimate the nutritional status and health of populations between 1720 and 1937. A project on "Secular Trends in Nutrition, Labor Welfare, and Labor Productivity" was established at NBER and by mid-1984 about 400,000 observations on height by age, covering 16 different populations, were in machine-readable form. The data on height by age were integrated with genealogical data to analyze the contribution of secular trends in nutrition to the secular decline in mortality. ${ }^{10}$

Consequently, when the issue arose of creating a life-cycle sample based on the veterans of the Union Army, the task seemed to be a logical extension of the types of synthetic data sets that cliometricians had been working with for some time and employing research designs and methods that were familiar to them. The principal break with the past stemmed from the copious medical histories of both acute and chronic diseases that were available in the military and 
pension records. Although the medical data required cliometricans to undertake crash courses in epidemiology and medical history, it was apparent that physicians would have to play a central role in the design and execution of the project from the start. Once the appropriate research team was assembled, we were ready to go and confident that we could manage the challenges of the project. And we were thrilled by the prospect of reconstructing and analyzing the burden of diseases that afflicted the first American cohorts to reach age 65 in the twentieth century.

\section{A Principal Finding}

The main accomplishment to date has been the accurate description of the burden of chronic diseases and disabilities that afflicted males aged 50 and over during the opening decades of the twentieth century and the last decade or two of the nineteenth century. ${ }^{11}$ Of course, the array of diseases that afflicted Americans was known to the physicians who treated them, and toward the end of nineteenth century this knowledge was codified in pathology books that medical students had to read. However, not much was known about the frequency of these conditions across the population since nationally representative statistics on civilian health were not collected in the United States until the introduction of the National Health Interview Survey (NHIS) in the 1960 s. $^{12}$

Prior to that time quantitative evidence on health came mainly from the information on cause of death in death certificates. However, the diseases that cause most deaths, even when reported accurately, are merely a subset of the disease burden of the living and poorly reflect the chronic conditions and disabilities of the living. Such diseases as arthritis, hernias, and dementia rarely appeared on death certificates but they sharply reduced capacity to work and undermined the quality of life for many aging veterans before World War II. Consequently, reliance on death certificates distorted the characterization of the chronic disease burdens of the living and the 
changes in these burdens over the course of the twentieth century. It was one factor that promoted the view, since shown to be incorrect, that for middle aged and elderly workers the duration of chronic conditions was shorter in a time when deaths were due primarily to infectious diseases rather than chronic diseases (cf. Harris 1997).

The Prevalence and Severity of Chronic Diseases and Disabilities

The Union Army data reveal the ubiquity of chronic health conditions during the century before World War II. Not only was the overall prevalence rate of these diseases much higher among the elderly than today, but they afflicted the teens, young adults and middle ages to a much greater extent than today. This fact is brought out by Table 1, which shows that more than 80 percent of all males aged 16-19 in 1861 and more than 70 percent of men ages 20-24 were examined for the Union Army. These examinees were overwhelmingly volunteers (less than 4 percent were drafted), who presumably thought they were fit enough to serve. Yet disability rates were higher than today. Even among teenagers more than one out of six was disabled, and among men aged 35-39, more than half were disabled. Despite their relatively young ages, cardiovascular diseases (mainly rheumatic) accounted for 11 percent of the rejections; hernias another 12 percent; eye, ear, and nose diseases 7 percent; tuberculosis and other respiratory diseases 7 percent; tooth and gum diseases 8 percent. Most of the other rejections were due to orthopedic conditions and general debility (Lee 2001).

These findings about the early onset of chronic diseases cast new light on the debate about the effect of increased longevity on the prevalence rates of chronic diseases. Those who argued that the effect of increased longevity was to increase the average duration of chronic disease assumed no delay in the average age of onset of these diseases. They were also influenced by cross-sectional evidence that showed some increases in disability rates during the 
1970s and 1980s, despite the continuing decline in mortality rates (Riley 1990 and 1991; Wolfe and Haveman 1990). It seemed plausible that various health interventions and environmental changes served to reduce the severity of diseases and thus delayed death without providing cures, as has been the case with AIDS.

However, as Table 2 shows, there has been a significant delay in the onset of chronic diseases during the course of the twentieth century. Men age 50-54 were 24 percent more likely to be free of all chronic conditions in 1994 than a century earlier. At age 60-64, white males today are two-and-a-half times more likely to be free of chronic diseases than their counterparts a century ago. Further light is shed on the issue by considering specific diseases (see Table 3). Arthritis began 11 years later among men who turned 65 between 1983 and 1992 than those turned age 65 between 1895 and 1910. The delay in the onset of a chronic condition was about 9 years for heart diseases, about 11 years for respiratory diseases (despite much higher rates of cigarette smoking), and nearly 8 years for neoplasms. ${ }^{13}$

Union Army veterans who endured poor health did not typically die quickly. Veterans who lived to be at least age 50, and who entered the pension system before age 51, lived an average of 24 years past age 50. Moreover, at their last examination on or before age 51, their average degree of disability was 58 percent, where 100 percent indicates complete incapacity for manual labor. Between age 50 and 60 disability ratings (controlled for age at death) continued to rise sharply, and then increased at a decreasing rate. It is worth noting that of the veterans who lived to be age 50, about 29 percent lived to be age 80 or more. For these "Old Old," the level of disability for manual labor averaged between 85 and 100 percent for a decade or more. Indeed, some survived with such high levels of disability for as much as a quarter of a century (Helmchen 2003). As Table 4 shows, survivors usually acquired more and more comorbidities as 
they aged. ${ }^{14}$ Those who lived past age 85 had twice as many comorbidities as those who died by age 55 .

Consideration of the sweep of the twentieth century puts the debate over the relationship between the increase in life expectancy and the change in the burden of chronic disease among the elderly in a new perspective. It now appears that the decline in morbidity rates paralleled the decline in mortality rates. Indeed, the delay in the onset of chronic disabilities between 1900 and the 1990 s for those who lived to age 50 was greater than the increase in life expectancy at age 50 over the same periods. The average delay in the onset of chronic conditions over the century was more than 10 years (Helmchen 2003). ${ }^{15}$ However, the average increase in male life expectancy was about 6.6 years (Bell, Wade, and Goss 1992).

\section{Measuring and Explaining the Decline in the Burden of Chronic Diseases during the Twentieth Century}

Several investigators in the Early Indicators project have begun the difficult task of constructing a comprehensive index of the change in the burden of chronic diseases at ages 50 and over during the twentieth century. One approach to this problem involves the creation of an index based on the number and particular combination of comorbidities. Initial analysis of the correlation of such an index with the degree of disability that surgeons assigned to pensioners is promising (Canavese and Linares 2003).

Comorbidities of chronic diseases are also one of the main determinants of the rate of deterioration in health today, predicting both the rate of decline in functional capacity and in longevity. According to one scale of comorbidities, an increase in one unit of a comorbidity index is the equivalent of being a decade older (Landi et al. 1999; Penninx et al. 1999; Stuck et al. 1999; Kazis et al. 1998; Charlson et al. 1994). It thus seems likely that functional forms relating a comorbidity index to both functional capacity and longevity can be estimated and the 
way in which these functions have shifted over the course of the twentieth century can be described. These functional forms can also be used to forecast advances in health and longevity during the twenty-first century.

\section{Explaining Changes in}

Specific Chronic Conditions and in Functional Limitations

One important step in the formulation of a global measure of change in the burden of chronic diseases is the explanation for the decline in specific conditions. Dora Costa (2000) has estimated the impact of public health and socioeconomic status factors at late developmental and young adult ages on risks of incurring chronic conditions at middle and late ages. Significant predictors included mortality rates in counties of enlistments, infectious diseases experienced during the Civil War, and being a prisoner of war. She focused on a set of chronic conditions for which clinical diagnoses were essentially the same in the early 1900s as today (such as lower back pain, joint problems, decreased breath or adventitious sounds, irregular pulse, and valvular heart disease). This procedure permitted her to estimate how much of the observed decline in the prevalence rates of comparable conditions was due to the reduction in specific risk factors. Prevalence rates for 1971-1980 were computed from the National Health and Nutrition Examination Survey (NHANES).

She found that elimination of exposure to specific infectious diseases during developmental and young adult ages explained between 10 and 25 percent of the declines in the specified chronic diseases of middle and late ages between 1900-1910 and 1971-1980. Occupational shifts were also important, accounting for 15 percent of the decline in joint 
problems, 75 percent of the decline in back pains, and 25 percent of the decline in respiratory diseases.

Costa (2002) pushed this line of analysis further by documenting the decline in functional limitations among U.S. men between ages 50 and 74 over the course of the twentieth century. A central issue is the factoring of the decline in functional limitations among three processes: the decline in the prevalence rates of specific chronic diseases, the reduction in the debilitating sequelae of these diseases, and the influence of new medical technologies that relieve and control the sequelae. Her analysis turned on five functional limitations: difficulty walking, difficulty bending, paralysis, blindness in at least one eye, and deafness in at least one ear. Prevalence rates of these limitations among men aged 50-74 were computed for the Union Army, NHANES (1988-1994) and NHIS (1988-1994).

On average these five functional limitations declined by about 40 percent during the course of the twentieth century. Using probit regressions, Costa attributed 24 percent of the decline to reduction in the debilitating effect of chronic conditions and 37 percent to the reduced rates of chronic conditions.

\section{The Significance of Changes in Body Size}

The contribution of improvements in body size as measured by stature, BMI, and other dimensions have run through the research of the Early Indicators project like a red line. The discovery of correlations in time series going back to the colonial period between changes in stature and changes in life expectancy for the U.S. were reported first in 1986, although it was

known as early as $1978 .{ }^{16}$ Pursuit of a variety of issues called attention to the significance of changes in body size to the long-term decline in chronic conditions and mortality. For example, Diane Lauderdale and Paul Rathouz (1999) sought to investigate the impact of unhealthy 
environments on genetic component of height. They hypothesized that an unhealthy environment might attenuate the effects of genotype. To test that hypothesis they constructed a sample of brothers who served in the Union Army. Their analysis showed that brothers from unhealthy counties had both higher variances in height and lower covariance in the heights of siblings than was expected from standard equations for measuring genetic influences in the heights of siblings. Study of the likelihood of developing specific diseases while in the service also pointed to the importance of stature. For example, short recruits were more likely to develop tuberculosis while in service than taller ones (Lee 1997; Birchenall 2003).

\section{The Gould Sample}

In 1995 Dora Costa discovered a sample of 23,000 recruits who were, for scientific reasons, more intensively examined than the typical recruit (Costa, forthcoming). Benjamin A. Gould, a leading astronomer and one of the founders of the National Academy of Sciences, who was in charge of the project, collected information on waist and hip circumference, lifting strength, vital capacity of lungs, height, weight, shoulder breadth, and chest circumference. The sample covered whites, blacks, and Native Americans. Costa linked a subsample of 521 white recruits who survived to 1900 to their pension records. She also compared the Union Army soldiers with soldiers measured in 1946-47, 1950, and 1988.

Over a span of one hundred years men in the military became taller and heavier, but their waist-hip and chest-shoulder ratios were unchanged. But the height increased by $5 \mathrm{~cm}$ and the BMIs of men aged 31-35 increased from 23 to 26. Controlling for BMI and age, the waist-hip and chest-shoulder ratios (both measures of abdominal fat) were significantly greater in the Gould sample than in the 1950 and 1988 samples. 
Using an independent competing risk hazard model to estimate the effect of changes in body shape on the risk of death from cerebrovascular and ischemic heart disease at older ages, she found that a low waist to hip ratio increased mortality by 4.4 times relative to the mean and controlling for BMI, while a high waist-hip ratio increased mortality risk by 2.9 times. Substituting the characteristics of soldiers in 1950 , who reached age 65 or over during the late 1980s, into her regression model produced a 15 percent decline in all cause mortality above age 64, implying that changes in frame size explain about 47 percent of the total decline in all cause mortality at older ages between the beginning and the end of the twentieth century.

\section{The Implication of Changes} in the Body Size of Women

Changes in the body builds of women have had a far-reaching effect on the reduction of perinatal and infant death rates since $1800 .{ }^{17}$ The impact of the improved builds of women is illustrated by Figure 1. The lines on this graph are normal approximations of the frequency distributions of birth weights. Birth weight is represented on the vertical axis, and the horizontal axis represents $z$-scores (deviations of birth weight from the mean measured in units of the standard deviations). Hence, the cumulative frequency distribution is represented by a straight line. The lowest line represents the distribution of United States nonwhites in 1950. They had a mean birth weight of 3218 grams and, as indicated by Figure 1, about 13 percent of the neonates weighed less than 2501 grams at birth. The second line is the distribution of birth weights for lower-class women in Bombay (Jayant 1964). Figure 1 indicates the mean birth weight in this population was just 2525 grams. In this case nearly half (46 percent) of the births were below the critical level, although the women in the sample were not the poorest of the poor.

The third curve is the probable distribution of the birth weights of the children of impoverished English workers about 1800 (Fogel 1986). The distribution of the birth weights in 
this class around 1800 probably had a mean of 2276 grams, which is about 249 grams (about half a pound) below the average in the deliveries of the lower-class women in Bombay. It follows that about 79 percent of the births among impoverished English workers around 1800 were at weights below 2501 grams. ${ }^{18}$

The implication of this distribution of birth weights is revealed by Table 5. Column 2 represents the actual schedule of neonatal death rates by weight for nonwhite United States males in 1950, and column 3 gives the actual distribution of their birth weights. ${ }^{19}$ The product of these two columns yields an implied neonatal death rate of 26.8 per 1,000, which, of course, was also the actual death rate. If, however, this United States population had had the distribution of the birth weights of the impoverished English workers of 1800, their neonatal death rates would have been 173.0 per thousand (see col. 3). The implication of Table 5 is that improvements in nutrition sufficient to shift the mean birth weight from 2276 grams to 3128 grams would have reduced the infant death rate by 83 percent.

Figure 1 reflects an important intergenerational influence on heath before the era of cesarean sections and of neonatal intensive care units. Malnourished mothers were small in stature and had small pelvic cavities, and they produced small children because of deficiencies in their diet and exposure to disease during pregnancy. As a result, the birth weight that minimized perinatal deaths was about 700 grams below that of the nonwhite U.S. women referred to in Figure 1. In other words, a condition for surviving the birth process was such a low birth weight that the neonate was at very high risk of dying shortly after birth. The escape from that dilemma is now almost universal in rich nations. Poor women accumulated biological capital at an intergenerational rate that was rapid enough to shift the birth weight of their children to a range that is about 1.7 times what it was two centuries ago. This means that less than 8 percent of all 
births in the United States and other rich nations are now below 2501 grams (Martin et al. 2002; Graafmans et al. 2002; Wilcox et al. 1995). ${ }^{20}$

\section{The Theory of Technophysio Evolution}

Recognition of environmentally induced changes in human physiology during the twentieth century that had a profound impact on the process of aging did not become apparent until mid-1993. The key finding was that prevalence rates in the main chronic diseases among Union Army veterans age 65 and older were much higher in 1910 than among veterans of World War II of the same ages during the mid-to-late 1980s. That finding was first set forth in a 1993 working paper (Fogel, Costa and Kim 1993) and was elaborated and subsequently characterized as a "theory of technophysio evolution" in Fogel 1994, Fogel 1997, Fogel and Costa 1997, Pope and Wimmer 1998, Fogel 1999, Fogel 2000, and Fogel 2002. The theory of technophysio evolution arose out of intense discussion among the senior investigators, consultants, and research assistants during 1993-1994, with the physicians providing much of the intellectual leadership. This theory points to the existence of a synergism between technological and physiological improvements that has produced a form of human evolution that is biological but not genetic, rapid, culturally transmitted, and not necessarily stable. The process is still ongoing in both rich and developing countries.

\section{Interpretation of the Theory}

Unlike the genetic theory of evolution through natural selection, which applies to the whole history of life on earth, technophysio evolution applies only to the last 300 years of human history, and particularly to the last century. ${ }^{21}$ Despite its limited scope, technophysio evolution appears to be relevant to forecasting likely trends over the next century or so in longevity, the age at onset of chronic diseases, body size, and the efficiency and durability of vital organ 
systems (Fogel and Costa 1997). It also has a bearing on such pressing issues of public policy as the growth in populations, in pension costs, and in health care costs.

The theory of technophysio evolution rests on the proposition that during the last 300 years, particularly during the last century, human beings have gained an unprecedented degree of control over their environment - a degree of control so great that is sets them apart not only from all other species, but also from all previous generations of Homo sapiens. This new degree of control has enabled Homo sapiens to increase its average body size by over 50 percent, to increase its average longevity by more than 100 percent, and to greatly improve the robustness and capacity of vital organ systems. ${ }^{22}$

\section{Implications of Technophysio Evolution for Analysis and Measurement}

Technophysio evolution implies that some theoretical propositions that underlie some current economic models are misspecified. For example, it is frequently assumed that individuals are born with a specific amount of health capital that depreciates over time. It is also assumed that the rate of depreciation depends on gross investments in health and on the level of health technology (which is assumed to be both exogenous to the individual and independent of the date

of birth-i.e., neglects cohort effects) (cf. Grossman 1972; Wagstaff and Dardanoni 1986; Wagstaff 1986). While these assumptions greatly simplify estimating procedures, they are inconsistent with accumulating evidence that successive birth cohorts are experiencing later onset of chronic diseases and disabilities, lower age-specific prevalence rates, and less severe conditions (Crimmins, Reynolds, and Saito 1999; Larson 1999; Jette et al. 1998; Freedman and Martin 1998).

The theory of technophysio evolution implies that individuals' initial endowments of health capital increased over the course of the twentieth century. This implication has been 
supported by recent research which has demonstrated that the curve of age-specific prevalence rates of chronic diseases has been shifting outward over the course of the twentieth century at what appears to be an increasing rate (Manton, Corder and Stallard 1997; Reynolds, Crimmins, and Saito 1998; Crimmins, Reynolds, and Saito 1999; Costa 2000 and 2002; Waidmann and Liu 2000; Manton and Gu 2001; Cutler 2001; Freedman, Martin, and Schoeni 2002). ${ }^{23}$

If the theory of technophysio evolution is correct, some of the assumptions currently used by health economists and others to measure and analyze the contribution of health interventions to improvements in life expectancy are misleading. In the standard models, endowments of individuals at birth are assumed to be the same, regardless of the year of birth. Without investments in improving health capital, different birth cohorts are assumed to experience the same average rates of decline in their original health endowments (i.e., no allowance is made for the slower average rates of decline in the untreated endowments of different "vintages" of health capital). Another problem is that a single health technology is presumed to exist that is exogenous to the individual.

The assumption that the endowment of human physiological capacity is fixed, so that medical intervention can only slow down the rate of deterioration in the original endowment, means that ways of forecasting future improvement in human physiology are sometimes neglected and possible paths of increase in health endowments play little role in forecasting future health care costs or longevity. ${ }^{24}$

The theory of technophysio evolution implies that health endowments in a given population change with the year of birth. It also points to complex interactions between date of birth and the outcome of exposures to given risk factors. Hence, not all improvements in the outcome of exposure to health risks between, say, 1970 and 1990 are due to health interventions 
during that period. Improvements in life expectancy may depend only partly on the more effective medical technologies of those years. It could also reflect the improved physiologies experienced by later birth cohorts that are due to improved technologies in food production, public health practices, personal hygiene, diets, and medical interventions put into place decades before 1970, and hence cannot be attributed exclusively, perhaps even primarily, to health inputs between 1970 and $1990 .^{25}$

The same set of considerations applies to efforts to explain the decline in disabilities during the twentieth century. The discovery that the average age of onset of disabilities is more than a decade later today than it was in 1900 , focuses attention on factors that might have improved the health endowments of successive cohorts or might have slowed down rates of depreciation before remedial medical interventions became necessary. ${ }^{26}$

The theory of technophysio evolution is also useful in circumstances where the standard models of health capital provide a useful first approximation. Improvements in health capital by date of birth have income effects that would lead individuals to make greater investments in health services. They also have substitution effects because they reduce the relative price of an additional year of life expectancy. Life at late ages becomes relatively more attractive, holding prices constant, because the later onset of chronic disabilities and a slower natural rate of deterioration in health increases the discounted present value of a year of consumption at late ages.

\section{Endogenous Treatment Technology}

The theory of technophysio evolution also suggests the need for a reconsideration of which health variables are endogenous and which are exogenous to individuals and families. For one thing, it implies that health technology is not static but in constant flux. Moreover, there is 
not just one useful technology available to the individuals at any point in time but many coexisting technologies of different vintages, and the rate of production of new technologies is accelerating. Hence, individuals may create their own unique technologies by the way they string together choices from among current and future technologies. For example a person with a given degree of osteoarthritis may choose to first treat the condition with over-the-counter antiinflammatory drugs, then shift to oral prescription drugs while waiting for improvements in surgical techniques and new plastics to emerge that reduce costs, increase the degree of success of an operation, and increase the durability of joint replacement. Such a string of choices defines an endogenous technology of treatment. Individuals thus create wide-ranging, person-specific technologies among which they can choose by the numerous permutations of strings of options.

Finally, the effectiveness of the numerous alternative technologies is not independent of the date of birth of a cohort. There are numerous studies indicating that the effectiveness of given treatments varies by physiological capacities which vary not only by age for a given cohort, but also across cohorts of different vintages. Race, ethnicity, gender, and nutritional status are significant variables in explaining the outcome of given health risks and the responses to different health interventions (Johnson 2000; Ferraro, Farmer, and Wybraniec 1997; Mendes de Leon et al. 1997; Davis et al. 1992 and 1994; Ostchega et al. 2000; Scrimshaw 1993, 1995, and 1997).

The point is not merely that a more complicated theory is needed, which recognizes the importance and implications of technologically based improvements in human physiology, some of which begin in utero, but that the increasing availability of longitudinal datasets, including the Union Army sample, is making it possible to estimate the critical change in the variables and 
parameters of dynamic models over time (cf. Parker 2000; Dasgupta 1993 and 1998; Manton and Land 2000a and b).

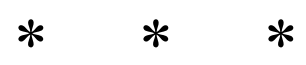

I am keenly aware that in this paper I have neglected several important lines of research in the Early Indicators project. These include a series of papers by Chulhee Lee on the factors that influenced the health and mortality of soldiers during the war, and the effect of wartime stress on subsequent health and labor force participation (Lee 1997, 1998, 1999a and b; 2003a, b, and c). There has also been a series of studies of specific diseases and disabilities, some of which are still at the working paper stage (Birchenall 2003; Wilson 2003; Wilson, Burton, and Howell 2003). One of the most promising new lines of research focuses on the impact of improved water supplies and other public health policies between 1880 and World War II on health and mortality (Troesken 2002, 2003, 2004; Troesken and Beeson 2003). The way in which politics and ideology affected the construction of Union Army pension law and the application of pension policy has been examined in a series of papers by Peter Blanck and Chen Song (2001, 2002, 2003; Blanck, Linares, and Song 2002). I hope to remedy the defects in today's report in a subsequent paper that will be presented to a conference on "Disparities in Chronic Disease and Disability" in November. 


\section{Notes}

1. On such variables such as wealth of parental households in 1850 and 1860, number of months unemployed in 1900 and 1910, and persons living in the veterans' households, the census records are superior, since this information is not contained in the pension records. That is why we linked the manuscript schedules of the census to the pension records.

2. Congress established the Union Army pension system in July 1862, providing pensions to soldiers who incurred permanent disabilities while in service. The amount of the pension depended on the degree of disability. All recruits, regardless of age, who served at least 90 days and were honorably discharged, could apply. In June 1890, Congress extended the pension to any veteran who was disabled, even if the disability was unrelated to war service. In 1904, by Executive Order, persons aged 62 were declared to be 50 percent disabled in their ability to perform manual labor. Thereafter, age alone made veterans eligible for pensions, although the amount of the pension still varied with the degree of disability (Glasson 1918).

3. The behavioral factors do not explain much of the variation in the odds of linking in either the prewar or the postwar censuses. The chi-square and R-square values are especially low in the postwar census, with the behavioral factors accounting for less than 3 percent of the variation in the probability of making a link.

4. Deserters were in most cases ineligible for a pension and many soldiers who died during the war had no dependent who was eligible. The foreign dummy is also significant in part because many of the foreigners who died during the early post-war years had no eligible 
dependents or served behind the front and so were less likely to incur war-related disabilities. However, those who survived to be eligible under the pension law of 1890 were as likely to be linked to pension records as natives.

5. These enterprises turned out to be highly successful, providing insights into processes that had heretofore been obscure, and promoting many new studies that successfully exploited these sources and analytical techniques. They also promoted new skills in sampling design, in analyzing sample selection biases, and in methods of correcting these and other biases by reweighting and by use of simulation models to estimate probable ranges of error and their impact on particular analytical issues.

6. The LDS genealogies, which are called "family histories," consist of three generations, but they can be linked together to construct large genealogies.

7. For example, persons outside the family line cannot be brought into the sample until marriage, because they are not at risk to die before marriage. When such caveats are heeded, it is possible to draw cross sections of persons alive in 1860 or 1870 from a sample of genealogies and compare these distributions of selected characteristics with the distributions of the same characteristics in the censuses. Such comparisons revealed that the genealogies produced representative cross sections when tested against such variables as wealth, household size, and age distributions.

8. This experience with genealogies provides the inspiration for future projects we are planning and influenced the conception of the new Project 7, "The Effect of Family on Adult Health and Welfare," led by Clayne Pope. It was submitted as part of the application for a competitive supplement last January. A project utilizing the genealogies has been in the planning for more than a decade. Much expertise has been accumulated in 
the utilization of this source of evidence. (See Wimmer and Pope 1975; Pope 1986, 1992; cf. Wimmer 2003.)

9. In fact, the figure of 17.0 for Norwegian girls was revised in subsequent publications, when better data had become available, to about 15.5 years; see Tanner 1981 .

10. Because of the limitations of space I have omitted a number of important developments in quantitative history between 1955 and 1985. More complete surveys are presented in Fogel and Elton 1983, Fogel 1992, Bogue 1983, and Jensen 1984, among other places.

11. We are exploring the possibility of drawing a representative sample of the hospital records to measure the burden of the chronic diseases of women at the beginning of the twentieth century.

12. Of course, the Public Health Service had long collected information on notifiable (contagious) diseases.

13. Since current diagnostic techniques make it possible to diagnose heart disease and neoplasms sooner in the development of these diseases than used to be the case c. 1910, the figures given in the text should be considered lower bounds on the delay in the onset of these conditions.

14. Comorbidity: the coexistence of two or more disease processes.

15. The delay in the average age of onset in chronic diseases can be decomposed into two parts: (1) the shift in the age-specific disease schedule; (2) the change in the distribution of ages due to the increase in life expectancy and the decline in the fertility rate. We have not yet completed this decomposition. However, preliminary estimates indicate that the contribution of the change in the age distribution was small. 
16. For reviews of earlier work dealing with the use of height, BMI and other anthropometric measures as indexes of changes in health and the standard of living over time, see Steckel 1995; Komlos and Cuff 1998.

17. For information on what is known about change in body size, and in rates of development of women over time and differences over space in recent decades, see Tanner 1981; Eveleth and Tanner 1976 and 1990; Friedman 1987; and John 1988 and 1992.

18. Tanner (1982) estimated that the Marine Society boys were 62 inches at maturity. Compared with the British military recruits of the same birth cohorts, the mature graduates of the Marine Society were about 5 inches shorter (Floud, Wachter and Gregory 1990, Table 4.1), suggesting that they belonged to the shortest 10 percent of the British laboring classes. It is likely that the women of this class were less than 59 inches. In populations this stunted, the differential in mean heights between men and women is in the range of 3 to 5 inches (cf. Friedman 1982; Eveleth and Tanner 1976, Tables 77, 78, $44,45)$.

19. The distribution of birth weights is not strictly normal because it is a convolution of two distributions: a main distribution of full-term babies and a smaller distribution of preterm babies. Hence in fitting normal approximations of birth weights it is common to discard the small distribution of preterm babies (Wilcox and Russell 1983; Wilcox et al. 1995; Graafmans et al. 2002). The weight distribution displayed in column 3 of Table 5 is estimated from the fitted normal curve, and it differs slightly from the original data as follows: 


\begin{tabular}{lcc} 
Birth Weight $(\mathrm{g})$ & Fitted Distribution & Original Distribution \\
\cline { 2 - 2 } 1,500 or less & 0.012 & 0.012 \\
$1,500-2,000$ & 0.014 & 0.015 \\
$2,001-2,500$ & 0.051 & 0.055 \\
$2,501-3,000$ & 0.182 & 0.188 \\
$3,001-3,500$ & 0.351 & 0.356 \\
$3,501-4,000$ & 0.260 & 0.253 \\
$4,001-4,500$ & 0.087 & 0.082 \\
4,501 or more & 0.046 & 0.040
\end{tabular}

I am grateful to Dr. Kwang-sun Lee for providing the comparison. As he pointed out in his letter of July 7, 2003, the difference in the two distributions is so small that it does not affect the thrust of my discussion of Table 5 .

20. However, obstructed labor is still a serious problem for small women in poor countries, where it kills many mothers and children (Rush 2000).

21. Costa and Fogel limit technophysio evolution to the last 300 years for two reasons. It was not until about 1700 that changes in technology permitted population growth far in excess of previous rates. Moreover, after 1700 body weight and stature increase to unprecedented levels. See Figure 1 in Fogel and Costa 1997.

22. Although a considerable body of empirical evidence has accumulated indicating that a "good" environment both speeds up biological development at young ages and delays the onset of chronic conditions at middle and late ages, there is as yet no agreed upon theory about the cellular and molecular processes that explains these observations.

23. Costa has noted that the annual rate of decline in functional limitations between 1900 and 1980 was substantially below the rate of decline since 1980 . That point is important 
because it bears on forecasts of the likely improvements in functional limitations during the twenty-first century.

Another question arises: How much of the total decline in the burden of disease and functional limitation that occurred in the United States during the twentieth century took place before 1980 and how much since then? A reliable answer to that question requires new data sets that will provide a more detailed picture of the temporal pattern of changes in the burden of chronic disabilities for cohorts who turned age 65 between 1915 and 1980 than we now have. An illustration of what that division might be is suggested by Costa's estimate that functional limitation declined at 0.6 percent per annum between 1900 and 1980, and Manton and Gu's estimate that during the 1980s and 1990s the average rate of decline in disability was 1.7 percent per annum. Together these estimates suggest a total decrease of 56 percent in the burden of disability after age 65 . About twothirds of the decline took place before 1980 and one-third after 1980.

This computation illustrates some of the problems that will need to be overcome in the measuring and explaining the decline in disabilities during the twentieth century. The measure of functional limitations needs to be consistent over the century (Costa and Manton and $\mathrm{Gu}$ used different measures of disability). There is also an issue of how to define the severity of different sets of conditions in different social and economic contexts. It is likely that several alternative indexes will have to be constructed, involving issues similar to those encountered in the construction of indexes of prices over long periods.

24. Among the exceptions are Rosenzweig and Schultz 1988 and Dasgupta 1993. 
25. Much recent research indicates that waiting time to the onset of chronic diseases is a function of exposure to insults in utero and infancy. See Barker 1998; Scrimshaw 1997.

26. Although I have focused on new technology for treatment much has been done to prevent early onset of chronic diseases by promoting better nutritional habits and lifestyles. 


\section{References}

Alter, George and James C. Riley. 1989. "Frailty, sickness, and death: Models of morbidity and mortality in modern populations," Population Studies 43(1): 25-45.

Bell, Felicitie C., Alice H. Wade, and Stephen C. Goss. 1992. Life Tables for the United States Social Security Area 1900-2080. Actuarial Study No. 107. Baltimore: U.S. Department of Health and Human Services, Social Security Administration, Office of the Actuary.

Birchenall, Javier A. 2003. "Airborne diseases: Tuberculosis in the Union Army." Paper presented at the Joint Meeting of the Early Indicators of Later Work Levels, Disease, \& Death Program Project and Cohort Studies groups, National Bureau of Economics, 25-26 April 2003, Cambridge, MA.

Blanck, Peter D., Claudia Linares, and Chen Song. 2002. "Evolution of disability in late 19th century America: Civil War pensions for Union Army veterans with musculoskeletal conditions," Behavioral Sciences and the Law 20(6): 681-697.

Blanck, Peter D. and Chen Song. 2001. "'With malice toward none; with charity toward all': Civil War pensions for native and foreign-born Union Army veterans,"Transnational Law and Contemporary Problems 11(1): 1-75.

Blanck, Peter D. and Chen Song. 2002. "Civil War pension attorneys and disability politics," University of Michigan Journal of Law Reform 35(1\&2): 137-217.

Blanck, Peter D. and Chen Song. 2003. "Never forget what they did here': Civil War pensions for Gettysburg Union Army veterans and disability in nineteenth century America," William and Mary Law Review 44(): 1109-71.

Bogue, Allan G. 1983. Clio and the Bitch Goddess: Quanitification in American Political History. Beverly Hills: Sage Publications.

Canavese, Paula and Claudia Linares. 2003. Alternative measures to the total disability rates, surgeon's certificates data. CPE Working Paper Series \#2003-2.

Ceruzzi, Paul E. 2003. A History of Modern Computing, 2nd ed. Cambridge, MA: MIT Press.

Charlson, M., T. P. Szatrowski, J. Peterson, and J. Gold. 1994. "Validation of a combined comorbidity index," Journal of Clinical Epidemiology 47(11): 1245-1251.

Costa, Dora L. 2000. "Understanding the twentieth-century decline in chronic conditions among older men," Demography 37(1): 53-72.

Costa, Dora L. 2002. "Changing chronic disease rates and long-term declines in functional limitation among older men,” Demography 39(1): 119-137. 
Costa, Dora L. Forthcoming. "The measure of man and older age mortality: Evidence from the Gould Sample," Journal of Economic History.

Crimmins, Eileen M., Sandra L. Reynolds, and Yasuhiko Saito. 1999. "Trends in health and ability to work among the older working-age population," Journals of Gerontology 54B(1): S31-S40.

Cutler, David M. 2001. "The reduction in disability among the elderly," Proceedings of the National Academy of Sciences, USA 98(12): 6546-6547.

Dasgupta, Partha. 1993. An Inquiry into Well-Being and Destitution. Oxford: Clarendon.

Dasgupta, Partha. 1998. "The economics of poverty in poor countries." Working paper, STICERD, London School of Economics Discussion Papers Series.

Davis, Maradee A., John M. Neuhaus, Deborah J. Moritz, and Mark R. Segal. 1992. "Living arrangements and survival among middle-aged and older adults in the NHANES I Epidemiologic Follow-Up Study," American Journal of Public Health 82(3): 401-406.

Davis, Maradee A., John M. Neuhaus, Deborah J. Moritz, David Lein, John D. Barclay, and Suzanne P. Murphy. 1994. "Health behaviors and survival among middle-aged and older men and women in the NHANES I Epidemiological Follow-Up Study," Preventive Medicine 23(3): 369-376.

Eveleth, Phyllis B. and J. M. Tanner. 1976. Worldwide Variation in Human Growth. Cambridge: Cambridge University Press.

Eveleth, Phyllis B. and J. M. Tanner. 1990. Worldwide Variation in Human Growth, 2d ed. Cambridge: Cambridge University Press.

Ferraro, Kenneth F., Melissa M. Farmer, and John A. Wybraniec. 1997. "Health trajectories: Long-term dynamics among black and white adults," Journal of Health and Social Behavior 38(1): 38-54.

Floud, Roderick, Kenneth Wachter, and Annabel Gregory. 1990. Height, health and history: Nutritional status in the United Kingdom, 1750-1980. Cambridge: Cambridge University Press.

Fogel, Robert William. 1986. "Nutrition and the decline in mortality since 1700: Some preliminary findings," in Long-Term Factors in American Economic Growth, eds. Stanley L. Engerman and Robert E. Gallman. Chicago: University of Chicago Press, pp. 439-555.

Fogel, Robert William. 1992. "Introduction: Notes on the art of empirical research in the social sciences during an age of plunging costs in data processing," in Without Consent or Contract, vol. 2, Evidence and Methods, eds. Robert William Fogel, Ralph A. Galantine, and Richard L. Manning. New York: W. W. Norton, pp. 1-41. 
Fogel, Robert William. 1993. "New sources and new techniques for the study of secular trends in nutritional status, health, mortality, and the process of aging," Historical Methods 26(1): 543.

Fogel, Robert William. 1994. "Economic growth, population theory, and physiology: The bearing of long-term processes on the making of economic policy," American Economic Review 84(3): 369-395.

Fogel, Robert William. 1997. "Economic and social structure for an ageing population," Philosophical Transactions of the Royal Society of London 353B(1356): 1905-1917.

Fogel, Robert William. 1999. "Catching up with the economy," American Economic Review 89(1): 1-21.

Fogel, Robert William. 2000. The Fourth Great Awakening and the Future of Egalitarianism. Chicago: University of Chicago Press.

Fogel, Robert William. 2002. "Auxology and economics," in Human Growth from Conception to Maturity, eds. G. Gilli, L. M. Schell, and L. Benso. London: Smith-Gordon, pp. 1-11.

Fogel, Robert William and Dora L. Costa. 1997. "A theory of technophysio evolution, with some implications for forecasting population, health care costs, and pension costs," Demography 34(1): 49-66.

Fogel, Robert William, Dora L. Costa, and John M. Kim. 1993. "Secular trends in the distribution of chronic conditions and disabilities at young adult and late ages, 1860-1988: Some preliminary findings." Paper presented at the National Bureau of Economic Research (NBER) Summer Institute, Economics of Aging Program, 26-28 July, Cambridge, MA.

Fogel, Robert William and Geoffrey R. Elton. 1983. Which Road to the Past? Two Views of History. New Haven: Yale University Press.

Fogel, Robert William, Stanley L. Engerman, James Trussell, Roderick Floud, Clayne L. Pope, and Larry T. Wimmer. 1978. "The economics of mortality in North America, 1650-1910: A description of a research project," Historical Methods 11(2): 75-108.

Fogel, Robert William, Michael Haines, Clayne L. Pope, Irwin H. Rosenberg, Nevin S. Scrimshaw, James Trussell, and Larry T. Wimmer. 1991. "Aging of Union Army men: A longitudinal study, 1830-1940." Program Project proposal submitted to the National Institute on Aging. Typescript, University of Chicago.

Foust, James D. 1968. The Yeoman Farmer and Westward Expansion of U.S. Cotton Production. Ann Arbor, MI: University Microfilms.

Freedman, Vicki A. and Linda G. Martin. 1998. "Understanding trends in functional limitations among older Americans," American Journal of Public Health 88(10): 1457-1462. 
Freedman, Vicki A., Linda G. Martin, and Robert F. Schoeni. 2002. "Recent trends in disability and functioning among older adults in the United States," JAMA 288(24): 3137-3146.

Friedman, Gerald C. 1982. "The heights of slaves in Trinidad," Social Science History 6(4): $482-515$.

Glasson, William Henry. 1918. Federal Military Pensions in the United States. New York: Oxford University Press.

Graafmans, W. C., J. H. Richardus, G. J. Borsboom, L. Bakketeig, J. Langhoff-Roos, P. Bergsjo, A. Macfarlane, S. P. Verloove-Vanhorick, J. P. Mackenbach, and the EuroNatal working group. 2002. "Birth weight and perinatal mortality: A comparison of 'optimal' birth weight in seven Western European countries," Epidemiology 13(5): 569-574.

Grossman, Michael. 1972. "On the concept of health capital and the demand for health," Journal of Political Economy 80(2): 223-255.

Harris, Bernard. 1997. "Growing taller, living longer? Anthropometric history and the future of old age," Ageing and Society 17(5): 491-512.

Helmchen, Lorens. 2003. Changes in the age at onset of chronic disease among elderly Americans, 1870-2000. Typescript, Center for Population Economics, University of Chicago.

Jayant, K. 1964. "Birth weight and some other factors in relation to infant survival: A study on an Indian sample," Annals of Human Genetics 27(3): 261-267.

Jensen, Richard J. 1984. "Historiography of American Political History," in Encyclopedia of American Political History: Studies of the Principal Movements and Ideas, vol. 1, ed. J. P. Greene. New York: Scribner's.

Jette, Alan M., Susan F. Assmann, Dan Rooks, Bette Ann Harris, and Sybil Crawford. 1998. "Interrelationships among disablement concepts," Journals of Gerontology 53A(5): M395M404.

John, A. Meredith. 1988. The Plantation Slaves of Trinidad, 1783-1816: A Mathematical and Demographic Inquiry. Cambridge: Cambridge University Press.

John, A. Meredith. 1992. "Logistic models of slave child mortality in Trinidad," in Without Consent or Contract: Conditions of Slave Life and the Transition to Freedom, Technical Papers, vol. 2, eds. Robert William Fogel and Stanley L. Engerman. New York: W. W. Norton, pp. 413-434.

Johnson, Nan E. 2000. "The racial crossover in comorbidity, disability, and mortality," Demography 37(3): 267-283.

Kazis, L. E., D. R. Miller, J. Clark, K. Skinner, A. Lee, W. Rogers, A. Spiro the 3rd, S. Payne, G. Fincke, A. Selim, and M. Linzer. 1998. "Health-related quality of life in patients served by 
the Department of Veterans Affairs: Results from the Veterans Health Study," Archives of Internal Medicine 158(6): 629-632.

Komlos, John and Timothy Cuff, eds. 1998. Classics in Anthropometric History. St. Katharinen, Germany: Scripta Mercaturae Verlag.

Landi, F., G. Zaccala, G. Gambassi, R. A. Incalzi, L. Manigrasso, F. Pagano, P. Carbonin, and R. Bernabei. 1999. "Body mass index and mortality among older people living in the community," Journal of the American Geriatrics Society 47(9): 1072-1076.

Larson, James S. 1999. "The conceptualization of health," Medical Care Research and Review 56(2): 123-136.

Lauderdale, Diane S. and Paul J. Rathouz. 1999. "Evidence of environmental suppression of familial resemblance: Height among U.S. Civil War brothers," Annals of Human Biology 26(5): 413-426.

Lee, Chulhee. 1997. "Socioeconomic background, disease, and mortality among Union Army recruits: Implications for economic and demographic history," Explorations in Economic History 34(1): 27-55.

Lee, Chulhee. 1998. "Long-term unemployment and retirement in early-twentieth-century America," Journal of Economic History 58(3): 844-56.

Lee, Chulhee. 1999a. "Farm value and retirement of farm owners in early-twentieth-century America," Explorations in Economic History 36(4): 387-408.

Lee, Chulhee. 1999b. "Selective assignment of military positions in the Union Army: Implications for the impact of the Civil War," Social Science History 23(1): 67-97.

Lee, Chulhee. 2001. "Exposure to disease during growing ages and service," in Early Indicators of Later Work Levels, Disease, \& Death, program project proposal submitted to the N. I. A. Typescript, Center for Population Economics, University of Chicago.

Lee, Chulhee. 2003a. "Prior exposure to disease and later health and mortality: Evidence from Union Army medical records," in Health and Labor Force Participation over the Life Cycle: Evidence from the Past, ed. Dora L. Costa. Chicago: University of Chicago Press for NBER, pp. 51-87.

Lee, Chulhee. 2003b. "Labor market status of older males in the United States, 1880-1940," Social Science History (forthcoming).

Lee, Chulhee. 2003c. "Health and economic mobility of Union Army recruits, 1860-1870." Paper presented at the NBER Early Indicators of Later Work Levels, Disease, and Death and Cohort Studies Groups Joint Meeting, Boston, 25-26 April. 
Manton, Kenneth G., Larry Corder, and Eric Stallard. 1997. "Chronic disability trends in elderly United States populations: 1982-1994," Proceedings of the National Academy of Sciences, USA 94(6): 2593-2598.

Manton, Kenneth G. and XiLiang Gu. 2001. "Changes in the prevalence of chronic disability in the United States black and nonblack population above age 65 from 1982 to 1999," Proceedings of the National Academy of Sciences, USA 98(11): 6354-6359.

Manton, Kenneth G. and Kenneth C. Land. 2000a. "Active life expectancy estimates for the U.S. elderly population: A multidimensional continuous-mixture model of functional change applied to completed cohorts, 1982-1996," Demography 37(3): 253-265.

Manton, Kenneth G. and Kenneth C. Land. 2000b. "Multidimensional disability/mortality trajectories at ages 65 and over: The impact of state dependence," Social Indicators Research 51(2): 193-221.

Martin, J. A., B. E. Hamilton, S. J. Ventura, F. Menacker, M. M. Park, and P. D. Sutton. 2002. "Births: Final data for 2001," National Vital Statistics Reports 51(2): 1-103.

Mendes de Leon, Carlos F., Laurel A. Beckett, Gerda G. Fillenbaum, Dwight B. Brock, Laurence G. Branch, Denis A. Evans, and Lisa F. Berkman. 1997. "Black-white differences in risk of becoming disabled and recovering from disability in old age: A longitudinal analysis of two EPESE populations," American Journal of Epidemiology 145(6): 488-497.

Menn, Joseph Karl. 1964a. The Large Slaveholders of Louisiana, 1860. New Orleans, LA: Pelican.

Menn, Joseph Karl. 1964b. The large slaveholders of the deep South, 1860. Ph.D. diss., University of Texas.

Murray, Christopher J. L. and Lincoln C. Chen. 1992. "Understanding morbidity change," Population and Development Review 18(3): 481-503.

Murray, Christopher J. L. and Lincoln C. Chen. 1993a. "Understanding morbidity change: Reply to Riley," Population and Development Review 19(4): 812-815.

Murray, Christopher J. L. and Lincoln C. Chen. 1993b. "In search of a contemporary theory of understanding mortality change," Social Science and Medicine 36(2): 143-155.

Ostchega, Yechiam, Tamara B. Harris, Rosemarie Hirsch, Van L. Parsons, and Raynard Kington. 2000. "The prevalence of functional limitations and disability in older persons in the US: Data from the National Health and Nutrition Examination Survey III," Journal of the American Geriatrics Society 48(9): 1132-1135.

Omran, Abdel R. 1991. "The epidemiological transition: A theory of the epidemiology of population change," Milbank Memorial Fund Quarterly 49(4): 509-538. 
Parker, Philip M. 2000. Physioeconomics: The basis for long-run economic growth. Cambridge, MA: MIT Press.

Penninx, B. W., S. Leveille, L. Ferrucci, J. T. van Eijk, and J. M. Guralnik. 1999. "Exploring the effect of depression on physical disability: Longitudinal evidence from the established populations for epidemiologic studies of the elderly," American Journal of Public Health 89(9): 1346-1352.

Pope, Clayne L. 1986. "Native adult mortality in the U.S.: 1770-1870," in Long-Term Changes in Nutrition and the Standard of Living, ed. Robert William Fogel. Bern: International Economic History Association, pp. 76-85.

Pope, Clayne L. 1992. "Adult mortality in America before 1900: A view from family histories," in Strategic Factors in Nineteenth Century American Economic History, eds. Claudia Goldin and Hugh Rockoff. Chicago: University of Chicago Press for NBER, pp. 267-296.

Pope, Clayne L. and Larry T. Wimmer. 1998. "Ageing in the early twentieth century," American Economic Review 88(2): 217-221.

Preston, Samuel H. and Michael Haines. 1991. Fatal Years: Child Mortality in Late NineteenthCentury America. Princeton, NJ: Princeton University Press.

Preston, Samuel H, Nathan Keyfitz, and Robert Schoen. 1972. Causes of Death: Life Tables for National Populations. New York: Seminar Press.

Reynolds, Sandra L., Eileen M. Crimmins, and Yasuhiko Saito. 1998. "Cohort differences in disability and disease presence," Gerontologist 38(5): 578-590.

Riley, James C. 1989. Sickness, Recovery and Death: A History and Forecast of Ill Health. Iowa City, IA: University of Iowa Press.

Riley, James C. 1990a. "Long-term morbidity and mortality trends: Inverse health transitions," in What We Know about Health Transition: The Cultural, Social and Behavioural Determinants of Health, The Proceedings of an International Workshop, Canberra, May 1989. Canbera: Health Transition Centre, Australian National University.

Riley, James C. 1990b. "The risk of being sick: Morbidity trends in four countries," Population and Development Review 16(3): 403-432.

Riley, James C. 1997. Sick, Not Dead: The Health of British Workingmen during the Mortality Decline. Baltimore: Johns Hopkins University Press.

Riley, James C. and George Alter. 1996. "The sick and the well: Adult health in Britain during the health transition," Health Transition Review 6(suppl.): 19-44.

Rosenzweig, Mark R. and T. Paul Schultz. 1988. "The stability of household production technology: A replication," Journal of Human Resources 23(4): 535-549. 
Rush, David. 2000. "Nutrition and maternal mortality in the developing world," American Journal of Clinical Nutrition 72(1 Suppl.): 212S-240S.

Scrimshaw, Nevin S. 1993. "Malnutrition, brain development, learning and behavior." The Twentieth Kamla Puri Sabharwal Memorial Lecture presented at Lady Irwin College, New Delhi, India, 23 November 1993.

Scrimshaw, Nevin S., ed. 1995. Community-Based Longitudinal Nutrition and Health Studies: Classical Examples from Guatemala, Haiti and Mexico. Boston: International Nutrition Foundation for Developing Countries (INFDC).

Scrimshaw, Nevin S. 1997. "More evidence that foetal nutrition contributes to chronic disease in later life," BMJ 315(7112): 825-826.

Soltow, Lee. 1975. Men and Wealth in the United States 1850-1870. New Haven: Yale University Press.

Steckel, Richard H. 1995. "Stature and the standard of living," Journal of Economic Literature 33(4): 1904-1940.

Stuck, A. E., J. M. Walthert, T. Nikolaus, C. J. Bula, C. Hohmann, and J. C. Beck. 1999. "Risk factors for functional status decline in community-living elderly people: A systematic literature review," Social Science \& Medicine 48(4): 445-469.

Tanner, J. M. 1981. A History of the Study of Human Growth. Cambridge: Cambridge University Press.

Tanner, J. M. 1982. "The potential of auxological data for monitoring economic and social wellbeing," Social Science History 6(4): 571-581.

Troesken, Werner. 2002. "The limits of Jim Crow: Race and the provision of the water and sewerage services in American cities, 1880-1925," Journal of Economic History 62(3): 73472 .

Troesken, Werner. 2003. Lead water pipes and infant mortality in turn-of-the-century Massachusetts. NBER Working Paper No. 9549.

Troesken, Werner. 2004. Water, race, and disease. Cambridge: MIT Press, in press.

Troesken, Werner and Patricia E. Beeson. 2003. "The significance of lead water mains in American cities: Some historical evidence," in Health and labor force participation over the life cycle, ed. Dora L. Costa. Chicago: University of Chicago Press for NBER, pp. 181-201.

Trussell, James and Richard Steckel. 1978. "The age of slaves at menarche and their first birth," Journal of Interdisciplinary History 8(3): 477-505.

U.S. National Office of Vital Statistics. 1954. "Weight at birth and its effect on survival of the newborn in the United States, early 1950," Vital Statistics Special Report 39(1). 
Verbrugge, Lois M. 1984. "Longer life but worsening health? Trends in health and mortality of middle-aged and older persons," Milbank Memorial Fund Quarterly Health and Society 62(3): 475-519.

Verbrugge, Lois M. 1989. "Recent, present, and future health of American adults," Annual Review of Public Health 10: 333-361.

Verbrugge, Lois M. and Alan M. Jette. 1994. "The disablement process," Social Science \& Medicine 38(1): 1-14.

Wagstaff, Adam. 1986. "The demand for health: Theory and applications," Journal of Epidemiology and Community Health 40(1): 1-11.

Wagstaff, Adam and Valentino Dardanoni. 1986. "The demand for health: A simplified Grossman model/A note on a simple model of health investment," Bulletin of Economic Research 38(1): 93-100.

Waidmann, Timothy, John Bound, and Michael Schoenbaum. 1995. "The illusion of failure: Trends in self-reported health of the U.S. elderly," Milbank Memorial Fund Quarterly 73(2): $253-287$.

Waidmann, Timothy A. and Korbin Liu. 2000. "Disability trends among elderly persons and implications for the future," Journals of Gerontology 55B(5): S298-307.

Wilcox, A., R. Skjaerven, P. Buekens, and J. Kiely. 1995. "Birth weight and perinatal mortality: A comparison of the United States and Norway," JAMA 273(9): 709-711.

Wilcox, A. J. and I. T. Russell. 1983. "Birthweight and perinatal mortality: II. On weightspecific mortality," International Journal of Epidemiology 12(3): 319-25.

Wilcox, Nathaniel T. 1992. "The overseer problem: A new data set and method," in Without Consent or Contract, vol. 2, Evidence and Methods, eds. Robert William Fogel, Ralph A. Galantine, and Richard L. Manning. New York: W. W. Norton, 84-108.

Wilson, Sven E. 2003. "The prevalence of chronic respiratory disease in the industrial era: The United States, 1895-1910," in Health and Labor Force Participation over the Life Cycle: Evidence from the Past, ed. Dora L Costa. Chicago: University of Chicago Press for NBER, pp. 147-180.

Wilson, Sven E, Joseph Burton, and Benjamin Howell. 2003. Work disability among non-elderly adult males: The United States, 1893-2001. Typescript, Brigham Young University.

Wimmer, Larry T. 2003. "Reflections on the Early Indicators project: A partial history," in Health and Labor Force Participation over the Life Cycle: Evidence from the Past, ed. Dora L. Costa. Chicago: University of Chicago Press for NBER. 
Wimmer, Larry T. and Clayne L. Pope. 1975. "The Genealogical Society Library of Salt Lake City: A source of data for economic and genealogical historians," Historical Methods Newsletter 8(2): 51-58.

Wolfe, Barbara L. and Robert Haveman. 1990. "Trends in the prevalence of work disability from 1962 to 1984, and their correlates," Milbank Memorial Fund Quarterly 68(1): 53-80. 


\section{Table 1}

\section{The Share of Northern White Males of Military Age Unfit for Military Service in 1861}

\begin{tabular}{lcc}
\hline Age & $\begin{array}{c}\text { Percentage of } \\
\text { Cohort } \\
\text { Examined }\end{array}$ & $\begin{array}{c}\text { Percentage of } \\
\text { Examinees Who } \\
\text { Were Rejected }\end{array}$ \\
\hline $16-19$ & 80.9 & 16.0 \\
$20-24$ & 70.4 & 24.5 \\
$25-29$ & 52.3 & 35.8 \\
$30-34$ & 41.0 & 42.9 \\
$35-39$ & 41.6 & 52.9 \\
\hline
\end{tabular}

Source: Fogel et al. 1991. 


\section{Table 2}

The Increase in the Proportion of White Males without Chronic Conditions during the Twentieth Century

\section{Proportion without Chronic Conditions}
Age Interval
1890-1910
c. 1994

$50-54$

0.33

0.41

$55-59$

0.21

0.29

$60-64$

0.10

0.25

65-69

0.03

0.14

Source: Helmchen 2003. 


\section{Table 3}

\section{Average Age of Onset of Some Chronic \\ Conditions among American Males near the Beginning and near the End of the Twentieth Century}

\begin{tabular}{lcc}
\hline Condition & $\begin{array}{r}\text { Men Born } \\
\mathbf{1 8 3 0}-\mathbf{1 8 4 5}\end{array}$ & $\begin{array}{c}\text { Men Born } \\
\mathbf{1 9 1 8}-\mathbf{1 9 2 7}\end{array}$ \\
\hline Heart disease & 55.9 & 65.4 \\
Arthritis & 53.7 & 64.7 \\
Neoplasm & 59.0 & 66.6 \\
Respiratory & 53.8 & 65.0 \\
\hline
\end{tabular}

Source: Helmchen 2003. 
Table 4

Average Number of Comorbidites among Veterans Who Lived To Be at Least Age 50

\begin{tabular}{ccc}
\hline $\begin{array}{c}\text { Average Age of } \\
\text { Death }\end{array}$ & $\begin{array}{c}\text { Percentage of } \\
\text { Veterans Who } \\
\text { Lived To at Least } \\
\text { Age 50, Who Died } \\
\text { in Interval }\end{array}$ & $\begin{array}{c}\text { Average Number of } \\
\text { Comorbidities at } \\
\text { Last Examination } \\
\text { before Death }\end{array}$ \\
\hline $50-54$ & 3.9 & 4 \\
$55-59$ & 6.4 & 5 \\
$60-64$ & 9.8 & 6 \\
$65-69$ & 14.0 & 6 \\
$70-74$ & 18.3 & 7 \\
$75-79$ & 19.1 & 7 \\
$80-84$ & 15.5 & 8 \\
$85-89$ & 9.0 & 7 \\
$90-94$ & 3.4 & 8 \\
95 or over & 0.7 & 7 \\
\hline
\end{tabular}

Source: Helmchen 2003. 


\section{Table 5}

\section{Effects of a Shift in the Distribution of Birthweights on the Neonatal Death Rate, Holding the Schedule of Death Rates (by Weight) Constant}

\begin{tabular}{|c|c|c|c|}
\hline $\begin{array}{l}\text { Weight } \\
\text { (grams) } \\
\text { (1) }\end{array}$ & $\begin{array}{c}\text { Neonatal } \\
\text { Death Rate of } \\
\text { Singleton } \\
\text { Nonwhite } \\
\text { U.S. Males } \\
\text { in } 1950 \\
\text { (per } 1,000) \\
(2)\end{array}$ & $\begin{array}{l}\text { Distribution of } \\
\text { Birthweights of } \\
\text { Singleton Nonwhite } \\
\text { U.S. Males in } 1950 \\
\begin{array}{c}(\bar{x}=3,128 \mathrm{~g} ; \\
\sigma=572 \mathrm{~g}) \\
(3)\end{array}\end{array}$ & $\begin{array}{l}\text { Distribution of } \\
\text { Birthweights in a } \\
\text { Population with } \\
\begin{array}{c}\bar{x}=2,276 \mathrm{~g} \\
\sigma=399 \mathrm{~g} \\
\text { (4) }\end{array}\end{array}$ \\
\hline 1,500 or less & 686.7 & 0.0117 & 0.1339 \\
\hline $1,501-2,000$ & 221.3 & 0.0136 & 0.2421 \\
\hline $2,001-2,500$ & 62.1 & 0.0505 & 0.3653 \\
\hline $2,501-3,000$ & 19.7 & 0.1811 & 0.2198 \\
\hline $3,001-3,500$ & 10.7 & 0.3510 & 0.0372 \\
\hline $3,501-4,000$ & 12.1 & 0.2599 & 0.0017 \\
\hline $4,001-4,500$ & 13.0 & 0.0865 & - \\
\hline 4,501 or more & 23.2 & 0.0456 & - \\
\hline $\begin{array}{l}\text { Implied } \\
\text { neonatal death } \\
\text { rate } \\
\text { (per } 1,000)\end{array}$ & & 26.8 & 173.0 \\
\hline $\begin{array}{l}\text { Possible infant } \\
\text { death rate } \\
\text { (per } 1,000)\end{array}$ & & 48.9 & 288.3 \\
\hline
\end{tabular}

Source: Cols. 2 and 3: U.S. National Office of Vital Statistics 1954; Col. 4: see Fogel 1986, nn. 21, 23, 24, and 26. 


\section{Figure 1}

\section{The Percentage of Male Births with Weights below 2,501 Grams in Two Modern Populations and of Poor English Workers during the Early Nineteenth Century}

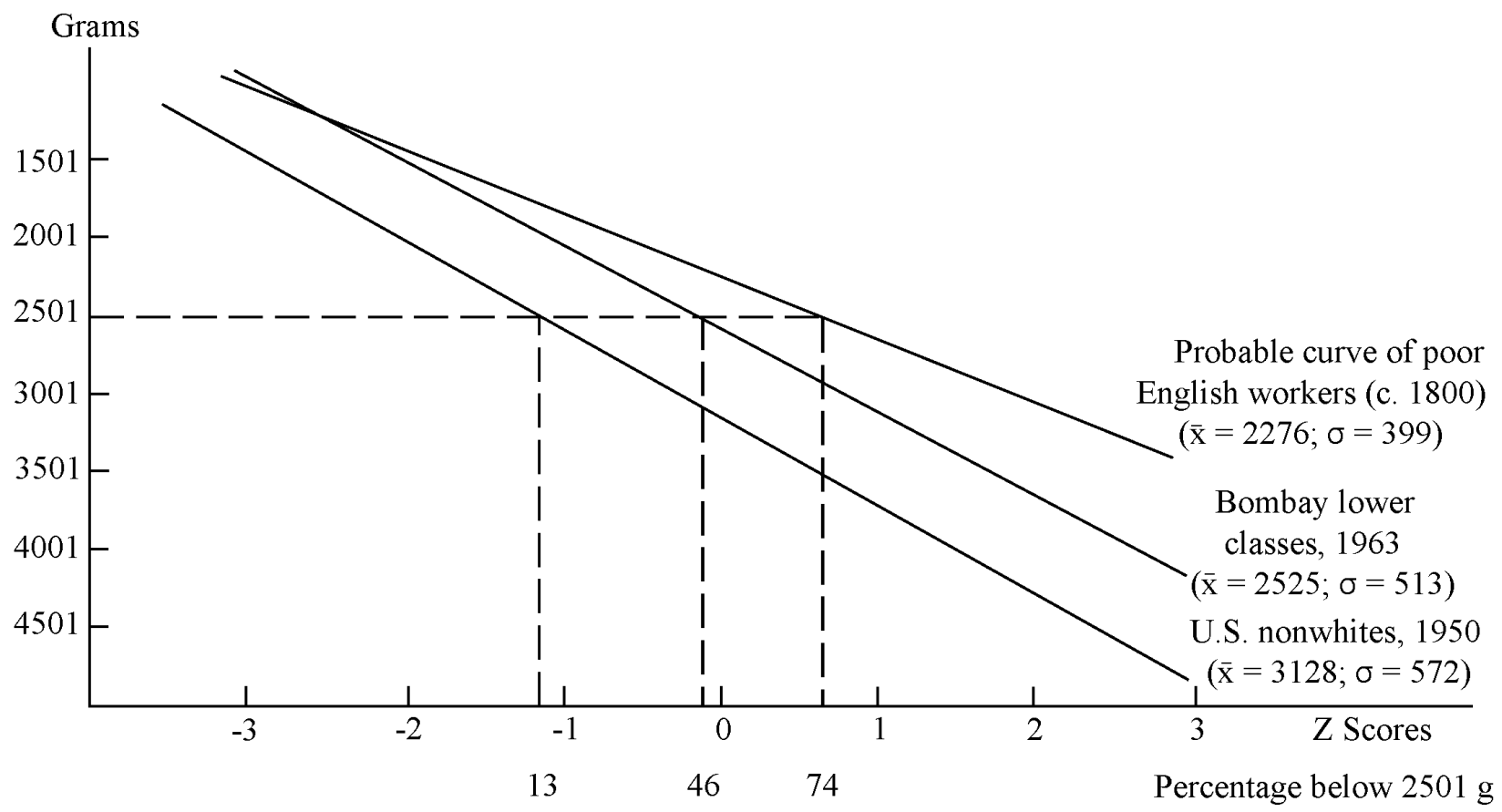

